\begin{tabular}{|l|l|}
\hline $\begin{array}{l}\text { Instituto de } \\
\text { Geriatria e Gerontologia }\end{array}$ & $\begin{array}{l}\text { Pan American Journal of Aging Research } \\
\text { PAJAR, Porto Alegre, v. 8, p. 1-9, jan.-dez. } 2020 \\
\text { ISSN-L: 2357-9641 }\end{array}$ \\
\hline http://dx.doi.org/10.15448/2357-9641.2020.1.38763 \\
\cline { 2 - 3 }
\end{tabular}

ARTIGO

\title{
Quality of life and mortality of Brazilian nonagenarians and centenarians with urinary incontinence
}

\author{
Qualidade de vida e mortalidade de nonagenários e centenários brasileiros com \\ incontinência urinária
}

Calidad de vida y mortalidad de nonagenarios y centenarios brasileños con incontinencia urinaria

\author{
Vivian Ulrich ${ }^{1}$ \\ orcid.org/0000-0002-3893-711X \\ viviulrich@gmail.com
}

\section{Susan Alexander ${ }^{2}$}

orcid.org/0000-0003-1665-7915 susan.alexander@uah.edu

\section{Angelo José Gonçalves \\ Bós ${ }^{1}$ \\ orcid.org/0000-0003-4.901-3155 \\ angelo.bos@pucrs.br}

Received on: Aug. $02^{\text {nd }}, 2020$ Accepted on: Nov. $16^{\text {th }}, 2020$

\section{(c) (i)}

Artigo está licenciado sob forma de uma licença Creative Commons Atribuição 4.0 Internacional.

\author{
ABSTRACT \\ OBJECTIVES: Urinary incontinence (UI) commonly occur in elderly people and it \\ is associated with reduced functionality, quality of life and survival in older adults \\ (65-80 years). Little is known about its impact in nonagenarians and centenarians. \\ Thus, this study aimed to evaluate the health and mortality of nonagenarians \\ and centenarians with UI.
}

METHODS: Nonagenarians and centenarians residents of Porto Alegre, Brazil, participated in this cohort study and were followed between 2016 to 2019. Survival analysis were performed using Cox Proportional Hazards Regression methods in the simple and adjusted models.

RESULTS: The overall prevalence of UI was 56\%, 64\% among women and $38 \%$ among men $(p<0.01)$. UI was more frequent in widowers $(p<0.01)$, those who left home $(p=0.02)$ and participated in social activities less frequently $(p=0.07)$. Also they had a higher frequency of chronic diseases $(p=0.02)$, more symptoms of depression $(p=0.08)$ and reduced cognitive performance $(p=0.04)$. Participants with UI had reduced survival in the simple (HR 0.29, $p=0.23$ ) and adjusted analysis (HR $0.33 \%, p=0.19)$. The variables that influenced the most, UI and mortality, were participation in social activities, ability to leave the home, cognitive performance and lower-limb function/mobility.

CONCLUSIONS: Although UI was not a direct predictor, it was associated with reduced survival. Nonagenarians and centenarians with UI will likely experience a lower risk of mortality if they continue to participate in social activities, preserve their cognitive performance and practice physical activities.

Key words: Public Health; Aging; Urinary incontinence; Survival analysis; Mortality.

RESUMO

OBJETIVOS: A incontinência urinária (IU) é frequente em idosos e associada a redução da funcionalidade, qualidade de vida e sobrevida em idosos mais jovens (65 a 80 anos), mas pouco se sabe sobre seu impacto em nonagenários e centenários. Assim, este estudo teve como objetivo avaliar a saúde e a mortalidade de nonagenários e centenários com IU.

MÉTODOS: Nonagenários e centenários residentes em Porto Alegre, Brasil, participantes de um estudo de coorte, foram acompanhados entre 2016 e 2019. A análise de sobrevida foi realizada usando os métodos de regressão de riscos proporcionais de Cox nos modelos simples e ajustados.

RESULTADOS: A prevalência geral de IU foi de $56 \%, 64 \%$ nas mulheres e $38 \%$ nos homens $(p<0,01)$. A IU foi mais frequente em viúvos $(p<0,01)$, que sairam de casa $(p=0,02)$ e participaram de atividades sociais com menos frequência $(p=0,07)$ Também apresentaram maior frequência de doenças crônicas $(p=0,02)$, mais sintomas de depressão $(p=0,08)$ e redução do desempenho cognitivo $(p=0,04)$. Participantes com IU tiveram sobrevida reduzida na análise simples (HR 0,29, p $=0,23$ ) e ajustada (HR 0,33\%, $p=0,19)$. As variáveis que mais influenciaram IU e 
mortalidade, foram participação em atividades sociais, capacidade de sair de casa, desempenho cognitivo e função / mobilidade de membros inferiores.

CONCLUSÕES: Embora a IU não seja um preditor direto, está associada à redução da sobrevida. Os nonagenários e centenários com IU provavelmente terão um risco menor de mortalidade se continuarem a participar de atividades sociais, preservar seu desempenho cognitivo e praticar atividades físicas.

Palavras-chave: Saúde pública; Envelhecimento; Incontinência urinária; Análise de sobrevida; Mortalidade.

\section{RESUMEN}

OBJETIVOS: La incontinencia urinaria (IU) ocurre comúnmente en personas mayores y se asocia con una funcionalidad, calidad de vida y supervivencia reducidas en adultos mayores (65-80 años). Se sabe poco sobre su impacto en nonagenarios y centenarios. Por lo tanto, este estudio tuvo como objetivo evaluar la salud y la mortalidad de nonagenarios y centenarios con IU. MÉTODOS: Nonagenarios y centenarios residentes en Porto Alegre, Brasil, participaron en este estudio de cohorte y fueron seguidos entre 2016 y 2019. El análisis de supervivencia se realizó utilizando métodos de regresión proporcional de riesgos de Cox en los modelos simple y ajustado.

RESULTADOS: La prevalencia global de IU fue de $56 \%$, $64 \%$ entre mujeres y $38 \%$ entre hombres $(p<0,01)$. La IU fue más frecuente en los viudos $(p<0,01)$, los que salieron de casa $(p=0,02)$ y participaron en actividades sociales con menor frecuencia $(p=0,07)$. También tenían mayor frecuencia de enfermedades crónicas ( $p$ $=0,02)$, más sintomas de depresión $(p=0,08)$ y menor rendimiento cognitivo $(p=0,04)$. Los participantes con IU tuvieron una supervivencia reducida en el análisis simple (HR 0,29, $p=0,23$ ) y ajustado ( $H R 0,33 \%, p=$ $0,19)$. Las variables que más influyeron, IU y mortalidad, fueron la participación en actividades sociales, la capacidad para salir del hogar, el rendimiento cognitivo y la función / movilidad de los miembros inferiores. CONCLUSIONES: Aunque la IU no fue un predictor directo, se asoció con una reducción de la supervivencia. Los nonagenarios y los centenarios con IU probablemente experimentarán un menor riesgo de mortalidad si continúan participando en actividades sociales, preservan su desempeño cognitivo y practican actividades físicas.

Palabras clave: Salud pública; Envejecimiento; Incontinencia urinaria; Análisis de supervivencia; Mortalidad.

\section{Introduction}

The aging process involves physiological changes that can facilitate the development of chronic, disabling and progressive diseases, compromising individuals' independence and autonomy. The loss of physical, social and cognitive function in this process are important topics. It is known that the number of nonagenarians and centenarians is rising, even in developing countries. Recent data from the Brazilian census demonstrated a total population growth of $12.3 \%$ from 2000 to 2010 , with an increase of $81 \%$ of nonagenarians and a decrease of $1.4 \%$ of centenarians ${ }^{1}$. Camacho et al. ${ }^{1}$ observed that $15 \%$ of nonagenarians who died between 2000 2010 did not receive medical assistance at the time of death, stating that, "...death is part of the life cycle, but dying without assistance, in precarious conditions or without a diagnosis, infringes the dignity of the human being"1. Furthermore, the high number of older adults who died without medical care suggests this population may have difficulty in accessing health care services and could be at risk of having care needs neglected. In this context, the need to identify factors related to survival, quality of life and quality of death in nonagenarians and centenarians was the main reason for the creation of the Project Multiprofessional Care for Oldest-Old (AMPAL), responsible for evaluating 245 people aged 90 years and older, since 2016. The participants were identified in the city of Porto Alegre, which contains 17 administrative regions called Participative Budgets Regions (PBR). Our research group randomly selected 8 census sectors from each PBR and performed a field search for nonagenarians and centenarians. Thereby, the AMPAL has a population-based approach.

Urinary incontinence (UI) commonly occurs in the elderly population and it is one of the Geriatric Giants. Recent studies about the impact of UI in nonagenarians and centenarians suggests that $\mathrm{UI}$ can increase fragility in this population, lead to more falls, fractures, longer periods of hospitalization, eventual institutionalization, reduce quality of life $\mathrm{e}^{2.3}$ and increase overall mortality ${ }^{4}$. In addition, evidence about the relationship between UI and mortality is needed, as well as greater knowledge about appropriate prevention strategies and treatment to increase quality of life motivated this study.

Our study sought to provide evidence on the relationships between UI and mortality in oldest-old and to serve as a basis for discussion of appropriate prevention strategies and treatment that promotes quality of life for this age group. The primary research question was: Is UI a predictor of overall mortality in Brazilian oldest-old? The additional objectives of the study included a characterization 
of the sociodemographic and clinical differences between oldest-old with and without UI.

\section{Methods}

The initial AMPAL survey interviewed the participants in their residences in Porto Alegre city, Brazil. The sample consisted of nonagenarians and centenarians initially evaluated in 2016 and followed until September 2019. The AMPAL research group followed participants regularly through phone calls or home visits.

The sample size calculation was based on the previous study of John et al. ${ }^{5}$. The authors observed overall mortality (all causes) between $20 \%$ and $25 \%$ in people with UI, compared with $10 \%$ in the group without UI. To observe this statistical difference with a confidence interval of $95 \%$ and a statistical power of $20 \%$, it would be necessary to observe and follow 64 participants. Therefore, our sample strategy satisfied the minimum requirements by interviewing 245 participants in 2016. The presence of UI was detected in all subjects who answered 'yes' to the question, । "Do you sometimes lose urine even if a little (one drop)?" during the 2016 assessment.

AMPAL participants were periodically monitored during different projects. The living status of participants (alive or deceased) was updated regularly by recording the most recent contact date or death date. The Funeral Service Center of Porto Alegre City assisted AMPAL by providing a monthly obituary of nonagenarian and centenarian residents to update our records. Hence, we were able to identify deaths in AMPAL participants and retrieve death dates from those who contact information was lost (due to unreported changes in addresses or phone numbers). In addition, we counted mortality for all possible causes. To confirm survival, the AMPAL research group contacted the presumed alive participants and recorded the last date of contact in the AMPAL Database.

When three call attempts on three different occasions were unsuccessful to contact the participant, the date of the last call was recorded in the AMPAL Database and used to calculate follow-up time. For the present study, the final contact date was August 30, 2019. Unreached participants after the first AMPAL evaluation in 2016 were excluded, since they had no follow-up time and the survival analysis were not included. For the participants that contact was lost, we included the last date of contact to calculate follow-up time.

The current study is part of an arm of the AMPAL approved by the PUCRS Research Ethics Committee, CAEE 55906216.0.0000.5336, registration number 1.639.961. The Scientific Committee approved the arm "Urinary Incontinence and Mortality in Nonagenarians and Centenarians from the AMPAL Project" of the PUCRS Institute of Geriatrics and Gerontology and the Research Ethics Committee of the same University (CAEE 96535418.2.0000.5336, registration number 2.956.258). All AMPAL participants signed the Informed Consent Form, allowing telephone contact after the initial assessment. The authors of the project committed to the confidential use of the AMPAL Database and to the monthly report provided by the Funeral Service Center of Porto Alegre City, signing the University Data Usage Agreement.

Descriptive analyses were performed to compare the sociodemographic and clinical characteristics of the oldest-old with and without UI. Categorical characteristics were tested with Chisquare test and mean difference were analyzed with student's t-test. We tested homogeneity of variances using Bartlett's test, when positive, the comparison of means was further examined with Kruskal-Wallis test. We adopted an alpha level of .05 for statistical significance 6 .

Survival analyses were calculated using Hazard Ratios (HR) for the simple and adjusted UI models applying Cox Proportional Hazard Models. Every time a death occurs, the probability of survival changes and adjustments in the number of people in the follow-up were necessary ${ }^{6}$. The participants' follow-up time, with a history of death by all causes, was calculated by the number of months between the initial AMPAL assessment and date of death. We contacted the participants without a registry of death to confirm survival and to calculate follow- 
up time. The simple analysis observed a possible survival difference in all participants. The adjusted analysis tested whether significant differences in clinical and sociodemographic characteristics, between groups with and without UI, influenced survival in the simple model.

\section{Results}

We excluded 11 participants due to the loss of contact. Therefore, our sample totalized 234 nonagenarians and centenarians, with a mean age of $92.3 \pm 3.62$ years. The majority of the participants were female (73\%), widow (67\%), lived with family (76\%) and were functionally literate (92\%).
Table 1 describes the sociodemographic characteristics of nonagenarians and centenarians with and without UI. The overall prevalence of UI was $56 \%, 64 \%$ in women and $38 \%$ in men ( $p<0.001$ ). The relationship between $\mathrm{UI}$ and marital status was more significant among widowers ( $p=0.005)$. Participants' age were similar between groups, although UI was more frequent among centenarians (71\%). UI was frequently reported by caucasian participants ( $\mathrm{p}=0.812$ ). In addition, the average years of schooling were lower in individuals with $U I$, they had a higher percentage of functional illiteracy $(p=0.390)$. Participants that lived alone had a higher frequency of UI, however this data was not statistically significant (58.33\%, p=0.820).

TABLE 1 - Sociodemographic characteristics of nonagenarians and centenarians with and without Urinary Incontinence (UI).

\begin{tabular}{|c|c|c|c|c|}
\hline \multicolumn{5}{|c|}{ UI } \\
\hline & No & Yes & Total & $\mathbf{P}$ \\
\hline \multicolumn{5}{|l|}{ Gender } \\
\hline Female & $62(36.47 \%)$ & $108(63.53 \%)$ & $170(72.65 \%)$ & 0.0003 \\
\hline Male & $40(62.5 \%)$ & $24(37.5 \%)$ & $64(27.35 \%)$ & \\
\hline Age (mean \pm SD) & $92.1 \pm 3.32$ & $92.5 \pm 3.85$ & $92.3 \pm 3.62$ & 0.4019 \\
\hline \multicolumn{5}{|l|}{ Age group } \\
\hline $90-94$ & $83(44.86 \%)$ & $102(55.14 \%)$ & $185(79.06 \%)$ & 0.4931 \\
\hline $95-99$ & $15(42.86 \%)$ & $20(57.14 \%)$ & $35(14.96 \%)$ & \\
\hline $100^{+}$ & $4(28.57 \%)$ & $10(71.43 \%)$ & $14(5.98 \%)$ & \\
\hline \multicolumn{5}{|l|}{ Ethnicity } \\
\hline White & $83(43.23 \%)$ & $109(56.77 \%)$ & $192(82.05 \%)$ & 0.8120 \\
\hline Non-white & $19(45.24 \%)$ & $23(54.76 \%)$ & $42(17.95 \%)$ & \\
\hline Level of schooling (years \pm SD) & $6.5 \pm 4.66$ & $6.3 \pm 7.78$ & $6.38 \pm 6.58$ & 0.8786 \\
\hline \multicolumn{5}{|l|}{ Can read and write } \\
\hline No & $6(31.58 \%)$ & $13(68.42 \%)$ & $19(8.12 \%)$ & 0.3897 \\
\hline Yes & $96(44.65 \%)$ & $119(55.35 \%)$ & $215(91.88 \%)$ & \\
\hline \multicolumn{5}{|l|}{ Marital status } \\
\hline Married & $31(63.27 \%)$ & $18(36.73 \%)$ & $49(20.94 \%)$ & 0.0049 \\
\hline Widow & $58(36.94 \%)$ & $99(63.06 \%)$ & $157(67.09 \%)$ & \\
\hline Other (Divorced/Single) & $13(46.43 \%)$ & $15(53.57 \%)$ & $28(11.97 \%)$ & \\
\hline \multicolumn{5}{|l|}{ Living arrangements } \\
\hline With caregiver & $10(50.00 \%)$ & $10(50.00 \%)$ & $20(8.55 \%)$ & 0.8202 \\
\hline With family & $77(43.26 \%)$ & $101(56.74 \%)$ & $178(76.07 \%)$ & \\
\hline Alone & $15(41.67 \%)$ & $21(58.33 \%)$ & $36(15.38 \%)$ & \\
\hline Total & $102(43.59 \%)$ & $132(56.41 \%)$ & $234(100.00)$ & \\
\hline
\end{tabular}

SD (Standard Deviation) 
Clinical and lifestyle characteristics of the participants are presented in Table 2. Participants with UI tend to leave home significantly fewer times a week $(p=0.021)$ and participate less in social activities $(p=0.074)$. Elderly that practice physical activity (26\%) demonstrated lower frequency of UI (52\%, $p=0.390)$. Relationships between participants' self-rated health and urine loss were not statistically significant $(p=0.25)$. However, participants with regular self-rated health presented urinary loss more frequently, significantly more NCDs ( $p=0.024)$ and lower scores on the mini-mental state examination $(p=0.042)$. Also, individuals with UI reported more symptoms of depression (1.6 $\pm 1.17, p=0.080$ ).

TABLE 2 - Clinical and lifestyle characteristics of nonagenarians and centenarians with and without Urinary Incontinence (UI).

\begin{tabular}{|c|c|c|c|c|}
\hline \multicolumn{5}{|c|}{ UI } \\
\hline & No & Yes & Total & $\mathbf{P}$ \\
\hline Leaves home (tpw $\pm S D)$ & $12.3 \pm 11.67$ & $8.9 \pm 10.48$ & $10.36 \pm 11.11$ & 0.0207 \\
\hline Receives visits (tpw \pm SD) & $1.7 \pm 1.01$ & $1.8 \pm 0.84$ & $1.77 \pm 0.92$ & 0.6388 \\
\hline Social participation (tpw $\pm S D$ ) & $0.6 \pm 1.40$ & $0.3 \pm 0.94$ & $0.44 \pm 1.17$ & 0.0742 \\
\hline \multicolumn{5}{|l|}{ Practice physical activity } \\
\hline No & $73(41.95 \%)$ & $101(58.05 \%)$ & $174(74.36 \%)$ & 0.3902 \\
\hline Yes & $29(48.33 \%)$ & $31(51.67 \%)$ & $60(25.64 \%)$ & \\
\hline \multicolumn{5}{|l|}{ General health } \\
\hline Bad or very bad & $9(45 \%)$ & $11(55 \%)$ & $20(8.66 \%)$ & 0.2567 \\
\hline Regular & $24(35.82 \%)$ & $43(64.18 \%)$ & $67(29.00 \%)$ & \\
\hline Good or excellent & $69(47.92 \%)$ & $75(52.08 \%)$ & $144(62.34 \%)$ & \\
\hline NCDs (mean $\pm S D)$ & $3.4 \pm 1.87$ & $3.9 \pm 2.22$ & $3.7 \pm 2.10$ & 0.0235 \\
\hline MMSE total (mean \pm SD) & $21.6 \pm 5.88$ & $19.9 \pm 6.96$ & $20.63 \pm 6.55$ & 0.0420 \\
\hline GDS5 total (mean \pm SD) & $1.4 \pm 1.09$ & $1.6 \pm 1.17$ & $1.52 \pm 1.14$ & 0.0800 \\
\hline \multicolumn{5}{|l|}{ GDS5 level } \\
\hline$<3$ & $86(45.5 \%)$ & $103(54.5 \%)$ & $189(80.77 \%)$ & 0.2265 \\
\hline$\geq 3$ & $16(35.56 \%)$ & $29(64.44 \%)$ & $45(19.23 \%)$ & \\
\hline Total & $102(43.59 \%)$ & $132(56.41 \%)$ & $234(100.00)$ & \\
\hline
\end{tabular}

tpw= Times per week, SD (Standard Deviation), NCDs (Noncommunicable diseases), MMSE (Mini-Mental State Examination), GDS5 (Geriatric Depression Scale of 5 questions).

During the follow-up time, after the initial contact in 2016, 70 participants died; 41 of those participants (58.6\%) reported UI in the baseline survey. Between the 164 survivors, 90 (54.9\%) reported UI in the baseline survey. Table 3 presents the hazard ratios for death event in the simple and adjusted UI models. We noted that no variable lost significance when adjusted for UI, however there were differences in the gender model associated with UI as a predictor of mortality risk. In the simple model, men were 6\% more likely to die than women (HR 1.06, $\mathrm{p}=0.782$ ). In the adjusted analysis, this chance increased 16\% ( $p=0.535$ ). The adjusted gender model allowed us to observe associations with other variables and UI. In the adjusted gender model the overall risk of death, in those that reported UI, increased from $29 \%$ to $33 \%$, although these data were not statistically significant $(p=0.188)$. 
TABLE 3 - Hazard ratio of death in simple and adjusted models for Urinary Incontinence (UI).

\begin{tabular}{|c|c|c|c|c|c|c|}
\hline & $\begin{array}{c}\text { Simple } \\
\text { HR (95\%-C.I.) }\end{array}$ & $\mathbf{P}$ & $\begin{array}{c}\text { Adjusted } \\
\text { HR (95\%-C.I.) }\end{array}$ & $\mathbf{P}$ & $\begin{array}{c}\text { UI } \\
\text { HR (95\%-C.I.) }\end{array}$ & $\mathbf{P}$ \\
\hline $\begin{array}{l}\text { Urinary } \\
\text { Incontinence } \\
\text { (UI) }\end{array}$ & $1.29(0.85-1.94)$ & 0.231 & & & & \\
\hline \multicolumn{7}{|c|}{ Sex (reference female) } \\
\hline Male & $1.06(0.68-1.65)$ & 0.782 & $1.16(0.73-1.82)$ & 0.535 & $1.33(0.86-2.03)$ & 0.188 \\
\hline \multicolumn{7}{|c|}{ Age group (ref. 100+) } \\
\hline $90-94$ & $0.34(0.17-0.67)$ & 0.002 & $0.35(0.18-0.69)$ & 0.002 & $1.25(0.83-1.89)$ & 0.277 \\
\hline $95-99$ & $0.65(0.30-1.40)$ & 0.276 & $0.67(0.31-1.44)$ & 0.309 & & \\
\hline \multicolumn{7}{|c|}{ Marital status (ref. Married) } \\
\hline $\begin{array}{l}\text { Other (single and } \\
\text { divorced) }\end{array}$ & $1.05(0.50-2.19)$ & 0.892 & $1.00(0.47-2.10)$ & 0.993 & $1.27(0.83-1.95)$ & 0.257 \\
\hline Widow & $1.10(0.67-1.82)$ & 0.691 & $1.02(0.60-1.71)$ & 0.932 & & \\
\hline $\begin{array}{l}\text { Social activities } \\
\text { participation }\end{array}$ & $0.32(0.16-0.66)$ & 0.002 & $0.33(0.16-0.70)$ & 0.004 & $1.12(0.74-1.70)$ & 0.567 \\
\hline Leaves home & $0.52(0.32-0.83)$ & 0.006 & $0.54(0.33-0.88)$ & 0.014 & $1.14(0.74-1.74)$ & 0.538 \\
\hline NCDs $\geq 10$ & $3.67(1.15-11.66)$ & 0.027 & $3.36(1.04-10.78)$ & 0.045 & $1.24(0.82-1.88)$ & 0.308 \\
\hline GDS $5 \geq 3$ & $2.54(1.35-4.78)$ & 0.003 & $2.48(1.32-4.66)$ & 0.005 & $1.23(0.82-1.88)$ & 0.307 \\
\hline MMSE & $0.93(0.91-0.95)$ & $<0.001$ & $0.93(0.92-0.96)$ & $<0.001$ & $0.93(0.60-1.44)$ & 0.757 \\
\hline
\end{tabular}

NCDs $\geq 10$ (More than 10 Noncommunicable diseases), GDS5 $\geq 3$ (Geriatric Depression Scale: 3 or more symptoms), MMSE (Mini Mental State Examination).

Moreover, UI influenced the survival prediction of variables. Those participants who reported the presence of $>/=10$ NCDs had HR of 3.67 in the simple and 3.36 in the adjusted model, maintaining statistical significance in both models $(p=0.045)$. The numbers of depressive symptoms in those with UI was significantly associated with risk of death in the simple and adjusted models (from 2.54 to 2.48). The most significant protectors of death in participants with UI were: social activities participation (reduced the risk of death to 12\%) and leave home (14\% lower risk). Adjusting for MMSE, participants without UI presented $7 \%$ lower risk of dying. Furthermore, lower limb performance was a predictor of mortality risk, those who reported both $\mathrm{Ul}$ and lower performance increased death risk in $8 \%$. These results suggests that a relationship between $\mathrm{UI}$ and mortality would be reduced in participants who continued to leave home, participate in social activities, improve cognition and engage in physical activities involving the lower limbs.

\section{Discussion}

Despite of the literature demonstrates that the prevalence of UI varies, our sample consisted in a great number of individuals with UI. In a population-based survey, the Profile of the Elderly in Rio Grande do Sul, 3.9\% of the interviewed reported urinary loss, while in the study of Marques, the prevalence was $29.4 \% 7.8$. Although the prevalence was generally higher in women, the percentage of men with $\mathrm{UI}$ in our analysis exceeded the reported in other studies ${ }^{2,8}$. Which might be explained by the inclusion of younger participants when compared to those in our sample. In addition, fewer studies describe 
the prevalence of UI in older men ${ }^{9,10}$.

Regarding the marital status, $75 \%$ of the participants with UI were widowers. These results are higher than the ones found by Tavares ${ }^{11}$, that reported a frequency of $44.5 \%$. In this study, they evaluated younger individuals, associated a higher frequency of IU with the absence of a partner, in which can be consider as an ally for elderly self-care ${ }^{11}$. Thus, we observed that nonagenarians and married centenarians seek help more frequently regarding UI, justifying the lower prevalence due to the marital status. In our research, the higher frequency of UI was among widowers, both men and women.

Evidences have demonstrated that UI has been associated with social isolation ${ }^{12}$. However, in our sample, participants with UI presented a lower frequency of leaving home and lower social activities participation. Furthermore, nonagenarians and centenarians with UI reported a similar frequency of receiving visits, relation not described in the literature yet, that suggests social restriction is conditioned to the difficulty of participation in social activities and leaving home. According to Candido et al. ${ }^{13}$, a social restriction may occur because of the fear of experiencing episodes of incontinence in public, visiting the bathroom frequently and fear of having the odor of urine on their bodies. This fear, a stigma associated with poor hygiene, may occur even in those who use incontinence management products such as tampons and/or adult diapers ${ }^{12}$. Morsch et al. observed that the elderly with UI were 40\% less likely to leave home, which would explain fears of embarrassment related to UI as a limiting factor in our study population ${ }^{14}$. However, we observed that while UI may reduce the frequency of attending social activities outside the house, it is not associated with receiving visitors. These suggests that self-imposed restrictions to home by those with UI may be more functional than social.

Bulut et al. ${ }^{15}$ have demonstrated greater frequencies of support in the NCDs observed in participants with $I U$, reporting the coexistence of geriatric syndromes among the elderly, especially $\mathrm{UI}$ in people aged 80 years or older. Among the geriatric syndromes observed, depression had a reduced prevalence among oldest-old ${ }^{15}$. In our analysis, UI was positively related to a higher frequency of depressive symptoms, supporting our conclusion about the emotional impact of $\mathrm{UI}$ in nonagenarians and centenarians.

In our sample, participants who reported UI had lower scores in the MMSE. However, it was unclear if UI was a predictor of cognitive decline. An interesting fact to observe is that we found lower scores in the cognitive function assessment of those who reported UI. Despite the lack of studies demonstrating this strong link, cognitive decline may be a risk factor for developing UI. A possible physiological explanation is found in the study of cerebral function; the control center of urination is in the frontal lobe of the brain and it seems plausible that neurodegenerative dysfunction in this area can trigger $\mathrm{UI}^{16}$.

After three years of follow-up, the difference in the frequency of $\mathrm{UI}$ between living and the deceased participants was less than $4 \%$. This difference was smaller than the observed by John et al. that studied a group of elderly with a younger mean age of 75 years ${ }^{5}$.

Our study had some limitations. First, we potentially underestimated results, since UI was determined by participants' self-report, individuals may have been embarrassed to address UI. Secondly, our follow-up time (three years) was shorter than others survival studies. Finally, the way to assess UI was another limitation; we carried out in a single question and did not use a validated questionnaire for urinary incontinence assessment.

\section{Conclusion}

Urinary incontinence was a common condition reported by nonagenarians and centenarians. Despite the higher prevalence among women, it is noteworthy that UI was also prevalent in men. Furthermore, we found that UI had a strong relationship with marital status, low frequency of leaving home, little participation in physical and social activities, and mental and physical health.

Our study emphasizes the importance of assessing the presence of incontinence, 
particularly in the oldest-old population. We observed that UI could exert a significant negative influence upon the person's quality of life. As a manageable condition, $U I$ is often disregarded because it may be considered as a normal aspect of aging or because patients are unwilling to discuss it. The unexpected high frequency of $\mathrm{UI}$ in our population demonstrates the reduced importance of assessing this health condition in men, even at younger ages. Although the advanced age, nonagenarians and centenarians may benefit from UI treatments, making it important for health professionals to assess regularly and manage $\mathrm{UI}$ in all patients, regardless the gender. Surveying nonagenarians and centenarians about $\mathrm{UI}$ and intervening earlier would potentially improve their participation in social activities and improve quality of life.

However, in our study UI was not a direct predictor of mortality, we observed that those with incontinence had a shorter survival rate. Perhaps, for nonagenarians and centenarians, a variety of conditions could better predict mortality than an isolated variable such as the presence of UI, even though this condition is an important component of functional assessment in this population. Our results suggest that $\mathrm{UI}$ has less impact on mortality in nonagenarians and centenarians and possibly the most significant impact of UI would be on the quality of life.

\section{Acknowledgments}

This study was financed in part by the Coordenação de Aperfeiçoamento de Pessoal de Nivel Superior - Brasil (CAPES) - Finance Code 001.

\section{REFERENCES}

1. Camacho NCA, Morche KR, Muller ALW, Bós AJG. Por que nonagenários não se tornam centenários no Brasil? [Why nonagenarians do not became centenarians in Brazil?] Revista da AMRIGS 2018;62(1):55-9.

2. Giraldo-Rodríguez L, Agudelo-Botero M, Mino-León D, Álvarez-Cisneros T. Epidemiology, progression, and predictive factors of urinary incontinence in older community-dwelling Mexican adults: Longitudinal data from the Mexican Health and Aging Study. Neurourology and Urodynamics 2019:38(7):1932-43. https://doi.org/10.1002/nau.24096
3. Wang CJ, Hung CH, Tang TC, Chen LY, Peng LN, Hsiao FY, Chen LK. Urinary Incontinence and Its Association with Frailty among Men Aged 80 Years or Older in Taiwan: A Cross-Sectional Study. Rejuvenation Res 2017; 20(2):111-17. https://doi.org/10.1089/rej.2016.1855

4. Amancio TG, Oliveira MLC, Amancio VS. Factors influencing the condition of vulnerability among the elderly. Rev Bras Geriatr Gerontol. 2019;22(2):e180159. https://doi.org/10.1590/1981-22562019022.180159

5. John G, Bardini C, Combescure C, Dällenbach P. Urinary Incontinence as a Predictor of Death: A Systematic Review and Meta-Analysis. Plos One 2016;11(7):e0158992. https://doi.org/10.1371/journal. pone.0158992

6. Bós AJG. Epilnfo sem mistérios: um manual prático [Epi Info without secrets: a practical handprint]. Porto Alegre: EDIPUCRS; 2012. 211p.

7. Bós DSG, Vianna MSS, Zanella AK. Prevalência de Incontinência Urinária em idosos gauchos IPrevalence of Urinary Incontinence in Southern Brazilian Older-Adults]. In: Bós AJG e orgs. Perfil dos Idosos do Rio Grande do Sul IProfile of Older-Adults from Rio Grande do Sul, Brazil]. Porto Alegre, 2015.

8. Marques LP, Schneider IJC, Giehl MWC, Antes DL, d'Orsi E. Demographic, health conditions, and lifestyle factors associated with urinary incontinence in elderly from Florianópolis, Santa Catarina, Brazil. Rev Bras Epidemiol. 2015;18(3):595-606. https://doi. org/10.1590/1980-5497201500030006

9. Searcy JAR. Geriatric Urinary Incontinence. Nurs Clin N Am 2017:52(3):447-55. https://doi.org/10.1016/j. cnur.2017.04.002

10. Colla C, Ghisleni AP, Paiva LL. Perfil de usuários que buscam atendimento fisioterapêutico para incontinência urinária em um centro de saúde do município de Porto Alegre IProfile of users seeking physiotherapy for Urinary Incontinence in a Health Care Center in Porto Alegre, Brazill. Rev. Saúde Públ. Santa Cat., 2015; 8(3):45-54.

11. Tavares DMS, Bolina AF, Dias FA, Santos NMF. Qualidade de vida de idosos com incontinência urinária [Life quality in older-adults with Urinary Incontinence]. Rev Eletr Enf. 2011; 13(4):695-702. https://doi.org/10.5216/ree.v13i4.12488

12. Matos MAB, Barbosa BLA, Costa MC, Rocha FCV, Almeida CAPL, Amorim FCM. The Urinary Incontinence Repercussions Towards the Elderly's Life Quality. Rev Fund Care Online 2019:11(3):567-75. https://doi. org/10.9789/2175-5361.2019.v11i3.567-575

13. Candido FJLF, Matnei T, Galvão LC, Santos VLJ, Santos MC, Sarris AB, et al. Incontinência urinária em mulheres: breve revisão de fisiopatologia, avaliação e tratamento [Urinary Incontinence in women: a short review on physiopathology, assessment, and treatment]. Visão acadêmica 2017; 18(3):67-80. https://doi. org/10.5380/acd.v18i3.54506

14. Morsch P, Pereira GN, Navarro JHN, Trevisan MD, Lopes DGC, Bós ÂJG. Características clínicas e sociais determinantes para o idoso sair de casa IClinical and social characteristics determining older-adults to leave homel. Cadernos de Saúde Pública. 2015, 31(5):1025-34. https://doi.org/10.1590/01021-311X00053014 
15. Bulut EA, Soysal P, Isik AT. Frequency and coincidence of geriatric syndromes according to age groups: single-center experience in Turkey between 2013 and 2017. Clin Interv Aging. 2018; 4(13):1899-905. https:// doi.org/10.2147/CIA.S180281

16. Ribeiro DKMN, Lenardt MH, Michel T, et al. Contributory factors for the functional independence of oldest old. Rev Esc Enferm USP 2015:49(1):89-95. https://doi. org/10.1590/So080-623420150000100012

\section{Mailing address}

Angelo José Gonçalves Bós

Pontifícia Universidade Católica do Rio Grande do Sul (PUCRS). Porto Alegre, RS, Brasil

Avenida Ipiranga 6681, prédio 40, sala 806

Partenon, 90619-900

Porto Alegre, RS, Brasil 